\title{
Whole-body retention of $\alpha$-linolenic acid and its apparent conversion to other $n-3$ PUFA in growing pigs are reduced with the duration of feeding $\alpha$-linolenic acid
}

\author{
Héctor R. Martínez-Ramírez, John P. Cant, Anna K. Shoveller, James L. Atkinson and \\ Cornelis F. M. de Lange* \\ Department of Animal and Poultry Science, Centre for Nutrition Modelling, University of Guelph, \\ Guelph, ON, Canada N1G $2 W 1$
}

(Submitted 24 April 2013 - Final revision received 5 November 2013 - Accepted 13 November 2013 - First published online 17 January 2014)

\begin{abstract}
In the present study, fifteen growing pigs were used to determine the whole-body oxidation, retention efficiency (RE) and apparent conversion (AC) of $\alpha$-linolenic acid (18:3n-3) to $n-3$ highly unsaturated fatty acids (HUFA), including EPA (20:5n-3) and DHA (22:6n-3). The pigs were fed a diet containing $10 \%$ flaxseed for $30 \mathrm{~d}$. Whole-body fatty acid composition was determined at initial (27.7 (SE 1.9$) \mathrm{kg}$ ), intermediate (day 15; 39.2 (SE 1.4) kg) and final (45.7 (SE 2.2) kg) body weight. On day 12, four pigs were fed $10 \mathrm{mg} / \mathrm{kg}$ of uniformly labelled ${ }^{13} \mathrm{C}-18: 3 n-3$ (single-bolus dose) to determine the oxidation of $18: 3 n-3$. Expired $\mathrm{CO}_{2}$ samples were collected for $24 \mathrm{~h}$ thereafter. The wholebody content of $n-3$ PUFA increased linearly $(P<0 \cdot 0001)$ with time; however, the content of $22: 6 n-3$ exhibited a quadratic response $(P<0 \cdot 01)$ with a peak occurring at $15 \mathrm{~h}$. As a proportion of intake, the RE of $18: 3 n-3$ tended to reduce with time $(P=0 \cdot 098)$. The AC of ingested $18: 3 n-3$ to the sum of $n-3$ HUFA was reduced with time $(P<0 \cdot 05 ; 12 \cdot 2 v .7 \cdot 53 \%$ for days $0-15$ and days $15-30$, respectively). The AC of $18: 3 n-3$ to $20: 5 n-3$ or $22: 6 n-3$ was lower than that to $20: 3 n-3$, both for days $0-15(P<0 \cdot 05 ; 1 \cdot 14$ or $1 \cdot 07 v .7 \cdot 06 \%)$ and for days $15-30(P<0 \cdot 05 ; 1 \cdot 51$ or $0.33 v .4 .29 \%$ ). The direct oxidation of $18: 3 n-3$ was 7.91 (SE 0.98 ) $\%$ and was similar to the calculated disappearance of $18: 3 n-3$ between days 0 and $30(8 \cdot 81$ (se $5 \cdot 24) \%$ ). The oxidation of $18: 3 n-3$ was much lower than that reported in other species. The AC of $18: 3 n-3$ to $n-3$ HUFA was reduced over time and that to $20: 3 n-3$ in the present study was much higher than that reported in other species and should be explored further.
\end{abstract}

Key words: Fatty acid oxidation: $\boldsymbol{n}$-3 PUFA: Apparent conversion: Pigs

Effective manipulation of the fatty profile in pork products to provide human health benefits of $\alpha$-linolenic acid (18:3n-3) and $n$-3 highly unsaturated fatty acids (HUFA) ( $n-3$ HUFA and all $n$-3 PUFA minus 18:3n-3) requires a quantitative understanding of the $n$ - 3 PUFA metabolism in growing pigs. Most mammalian species, including pigs, are able to metabolise $18: 3 n-3$ to $n$ - 3 HUFA such as EPA (20:5n-3), docosapentaenoic acid $(22: 5 n-3)$ and DHA $(22: 6 n-3)^{(1)}$. Previous studies in pigs have shown that the inclusion of $18: 3 n-3$ from either ground flaxseed (FS, up to $15 \%$ in the diet) ${ }^{(2)}$ or rapeseed oil $(10 \%$ in the diet $)^{(3)}$ in pre-slaughter diets represents an effective means to incorporate significant amounts of $18: 3 n-3$ and $n-3$ HUFA in edible pork tissues, generating value-added healthy pork products for consumers without compromising pork quality $^{(2,3)}$. In the study of Romans et $a l^{(2)}$, it was observed that the incremental retention of $18: 3 n-3$ and $n-3$ HUFA in pork tissues decreased over time when feeding a $15 \%$ FS-containing diet, suggesting that the retention efficiency (RE) of $18: 3 n-3$ and apparent conversion (AC) of $18: 3 n-3$ to $n-3$ HUFA decrease with the duration of feeding 18:3n-3. However, the RE and AC of $18: 3 n-3$ on a whole-body basis in growing pigs consuming diets containing FS (as a source of $18: 3 n-3)$ are still unknown. Furthermore, and in contrast to other species $^{(4,5)}$, the oxidation rate of $18: 3 n$-3, determined directly using isotope tracers, has not been quantified in growing pigs; instead, mass balance calculations based on serial slaughter measurements have been used to indirectly estimate the oxidation (i.e. disappearance) of $18: 3 n-3$ in growing pigs $^{(6)}$. Therefore, the objective of the present study was to determine the whole-body RE of $18: 3 n-3$ and its AC to $n-3$ HUFA in growing pigs fed a $10 \%$ FS-containing diet, utilising the mass balance approach and serial slaughter observations.

Abbreviations: AC, apparent conversion; AID, apparent ileal digestibility; BW, body weight; FA, fatty acid; FS, flaxseed; HUFA, highly unsaturated fatty acids; $\mathrm{RE}$, retention efficiency; $\mathrm{U}-^{13} \mathrm{C}-18: 3 n-3$, uniformly labelled ${ }^{13} \mathrm{C}-18: 3 n-3$. 
In addition, the oxidation of $18: 3 n-3$ was measured directly by feeding a single-bolus dose of uniformly labelled ${ }^{13} \mathrm{C}-18: 3 n-3$ (U- $\left.{ }^{13} \mathrm{C}-18: 3 n-3\right)$.

\section{Materials and methods}

\section{Experimental animals, diets and general design}

The University of Guelph Animal Care Committee approved the present experimental protocol. A total of fifteen healthy purebred Yorkshire growing gilts from eight litters and weighing approximately $20 \mathrm{~kg}$ body weight (BW; 8-9 weeks old) were obtained from the University of Guelph Arkell Swine Research Station herd and transported to the animal metabolism unit. Before the start of the experiment, the pigs were fed ad libitum a maize, wheat and soyabean meal-based pig starter diet, which was assumed to be low in $n-3$ PUFA content. Upon arrival to the unit, the pigs were housed individually in fully slatted floor pens in an environmentally controlled room and were given free access to water via nipple drinkers ${ }^{(7)}$. The pigs were fed ad libitum a FS-free adaptation diet (Table 1) until weighing approximately $27 \mathrm{~kg}$ BW (Fig. 1). At the start of the experiment, four pigs from four different litters (initial BW 27.7 (SE 0.96) kg) were slaughtered to determine the initial chemical and physical body composition. The remaining pigs were randomly assigned to one of two different slaughter groups on day 15 ( $n$ 6; days $0-15)$ and day 30 ( $n$ 5; days $15-30$ ). The pigs were fed a maize, wheat and soyabean meal-based diet containing $10 \%$ ground FS $(15.5 \mathrm{~g} / \mathrm{kg}$ of $18: 3 n-3)$. Throughout the experiment, the pigs were fed three times a day (07.00, 15.00 and 23.00 hours); feed intake levels were fixed at $70 \%$ of the voluntary daily digestible energy intake according to the National Research Council $^{(8)}$. The pigs were weighed weekly to monitor growth rate and to adjust feeding levels. Feed refusals were collected daily and weighed weekly to calculate the actual feed intakes. In a subsample of four pigs, the oxidation of $18: 3 n-3$ was measured directly based on feeding a single-bolus dose of $\mathrm{U}^{13} \mathrm{C}-18: 3 n-3$ on day 12 after the start of the FS-containing diet feeding period.

The experimental diets were prepared at the University of Guelph feed mill. The experimental diets were formulated to contain equal amounts of $n-6$ and $n-3$ PUFA. The dietary contents of essential nutrients, including standardised ileal digestible indispensable amino acids, exceeded the requirements of pigs with high lean gain potentials ${ }^{(8)}$. The diets were fed in a pelleted form. Titanium oxide was added to the experimental diets as an indigestible marker for the assessment of nutrient digestibility.

\section{Serial slaughter procedure and nutrient analysis}

The pigs were killed using sodium pentobarbital on day 0,15 or 30 after the start of the FS-containing diet feeding period. On days 15 and 30, representative digesta samples were quickly collected from the last metre of the distal ileum, by gently squeezing the isolated gut segment, and frozen at $-80^{\circ} \mathrm{C}$ until later analyses ${ }^{(9)}$. Slaughter procedures and
Table 1. Ingredient composition and nutrient content of the adaptation diet (fed between 20 and $27 \mathrm{~kg}$ body weight (BW)) and the grower diet (fed for $30 \mathrm{~d}$ between 28 and $45 \mathrm{~kg} \mathrm{BW}$ )

\begin{tabular}{|c|c|c|}
\hline & $\begin{array}{l}\text { Adaptation } \\
\text { diet }\end{array}$ & $\begin{array}{c}\text { Grower } \\
\text { diet }\end{array}$ \\
\hline \multicolumn{3}{|l|}{ Ingredient composition (\%, as fed) } \\
\hline Maize & $40 \cdot 00$ & 34.39 \\
\hline Wheat & $20 \cdot 00$ & $20 \cdot 00$ \\
\hline Soyabean meal & 35.00 & 31.50 \\
\hline Ground flaxseed & - & $10 \cdot 00$ \\
\hline Fat, animal and vegetable blend & 1.00 & - \\
\hline L-Lys $\mathrm{HCl}$ & 0.20 & 0.20 \\
\hline DL-Met & $0 \cdot 12$ & $0 \cdot 13$ \\
\hline L-Thr & 0.13 & 0.15 \\
\hline Lincomycin* 44 & $0 \cdot 10$ & $0 \cdot 10$ \\
\hline Limestone & $1 \cdot 15$ & $1 \cdot 15$ \\
\hline Dicalcium phosphate & 1.30 & 1.22 \\
\hline Salt & 0.40 & 0.45 \\
\hline Swine vitamin and mineral mix $\dagger$ & 0.60 & 0.60 \\
\hline Titanium dioxide & $0 \cdot 10$ & $0 \cdot 10$ \\
\hline Vitamin Eł & - & 0.01 \\
\hline \multicolumn{3}{|l|}{ Calculated nutrient content§ } \\
\hline Digestible energy (MJ/kg) & $14 \cdot 6$ & $14 \cdot 7$ \\
\hline Crude protein (\%) & $22 \cdot 6$ & $22 \cdot 6$ \\
\hline Crude fat (\%) & $3 \cdot 61$ & $5 \cdot 69$ \\
\hline Total Lys (\%) & 1.40 & 1.35 \\
\hline Digestible Lys (\%)\| & $1.25(100)$ & $1.21(100)$ \\
\hline Digestible Met + Cys (\%) & $0.76(61)$ ฯ & $0.77(64)$ \\
\hline Digestible Thr (\%) & $0.85(68)$ & $0.86(71)$ \\
\hline Digestible Trp (\%) & $0.27(21)$ & $0.27(22.5)$ \\
\hline $\mathrm{Ca}(\%)$ & 0.80 & 0.80 \\
\hline $\mathrm{P}(\%)$ & $0 \cdot 70$ & $0 \cdot 70$ \\
\hline $\mathrm{Na}(\%)$ & 0.18 & 0.20 \\
\hline \multicolumn{3}{|l|}{ Analysed nutrient content (\%) } \\
\hline $\mathrm{DM}$ & $90 \cdot 9$ & $92 \cdot 0$ \\
\hline Crude protein & $21 \cdot 6$ & $22 \cdot 0$ \\
\hline Crude fat & 4.00 & 5.93 \\
\hline Ash & $6 \cdot 39$ & 6.96 \\
\hline $\mathrm{Ca}$ & $0 \cdot 78$ & 0.69 \\
\hline$P$ & 0.65 & 0.63 \\
\hline $\mathrm{Na}$ & $0 \cdot 17$ & $0 \cdot 18$ \\
\hline \multicolumn{3}{|l|}{ Fatty acid content ( $\mathrm{g} / \mathrm{kg}$, as fed) } \\
\hline Myristic acid $(14: 0)$ & $0.28(0.93)$ & $0.09(0.20)^{\star \star}$ \\
\hline Palmitic acid $(16: 0)$ & $5.45(18.3)$ & $4.47(9.74)$ \\
\hline Palmitoleic acid $(9 c-16: 1)$ & $0.29(0.97)$ & $0.08(0.17)$ \\
\hline Stearic acid $(18: 0)$ & $2.43(8.13)$ & $2 \cdot 13(4.64)$ \\
\hline Oleic acid $(9 c-18: 1)$ & $7 \cdot 82(26 \cdot 2)$ & $9.63(21.0)$ \\
\hline Linoleic acid (18:2 n-6) & $11.9(39.8)$ & $13.7(29.8)$ \\
\hline Arachidonic acid $(20: 4 n-6)$ & $0.19(0.64)$ & ND \\
\hline$\alpha$-Linolenic acid (18:3n-3) & $0.99(3.31)$ & $15.5(33.8)$ \\
\hline EPA $(20: 5 n-3)$ & $0.03(0.09)$ & ND \\
\hline DHA (22:6n-3) & $0.11(0.38)$ & ND \\
\hline$n-6: n-3$ PUFA ratio & $10 \cdot 7$ & 0.89 \\
\hline$\Sigma S F A$ & 8.25 & $6 \cdot 81$ \\
\hline ¿MUFA & 8.26 & $9 \cdot 82$ \\
\hline ¿PUFA & $13 \cdot 3$ & $29 \cdot 3$ \\
\hline$\Sigma S F A / \Sigma P U F A$ & 0.619 & 0.232 \\
\hline
\end{tabular}

ND, not detected.

* Supplied $44 \mathrm{mg} / \mathrm{kg}$ diet as lincomycin hydrochloride.

† Supplemented by $\mathrm{kg}$ of diet: vitamin A, $1.2 \mathrm{mg}$; vitamin $\mathrm{D}_{3}, 10 \mu \mathrm{g}$; vitamin $\mathrm{E}$, $16 \mathrm{mg}$; vitamin K, $1 \mathrm{mg}$; choline, $200 \mathrm{mg}$; pantothenic acid, $6 \mathrm{mg}$; riboflavin, $2 \mathrm{mg}$; folic acid, $0.8 \mathrm{mg}$; niacin, $10 \mathrm{mg}$; thiamin, $0.6 \mathrm{mg}$; vitamin $\mathrm{B}_{6}, 0.6 \mathrm{mg}$; biotin, $0.08 \mathrm{mg}$; vitamin $\mathrm{B}_{12}, 0.01 \mathrm{mg}$. Supplemented by $\mathrm{kg}$ of diet: $\mathrm{Na}, 1800 \mathrm{mg}$; $\mathrm{Cu}$ (from $\mathrm{CuSO}_{4}$ ), $15 \mathrm{mg} ; \mathrm{Zn}$ (from $\mathrm{ZnO}$ ), $100 \mathrm{mg} ; \mathrm{Fe}$ (FeO), $100 \mathrm{mg}$; $\mathrm{Mn}\left(\mathrm{MnSO}_{4}\right), 20 \mathrm{mg}$; I (KI), 0.3 mg; Se $\left(\mathrm{Na}_{2} \mathrm{SeO}_{3}\right), 0.3 \mathrm{mg}$.

$\ddagger$ Concentration of vitamin E: $500 \mathrm{mg} / \mathrm{g}$ of product.

$\S$ Based on the National Research Council ${ }^{(8)}$.

॥ Represents digestible standardised ileal digestibility.

q $100 \times$ ratio to Lys.

${ }^{\star \star}$ Values in parentheses are fatty acid profile, given as percentage of analysed fat content. 


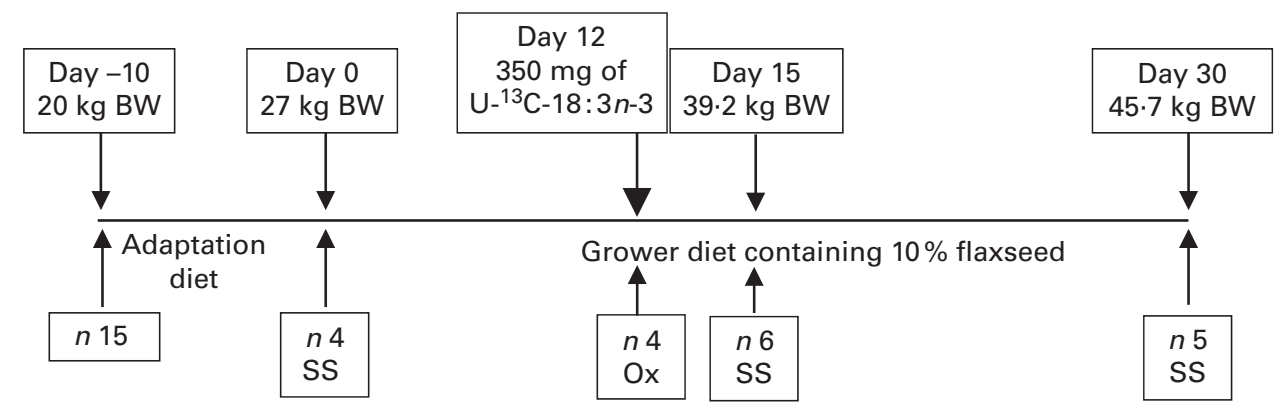

Fig. 1. Schematic representation of the experimental design. Feed intake was fixed at $70 \%$ of the voluntary feed intake based on the National Research Council ${ }^{(8)}$. On day $12,10 \mathrm{mg}$ of uniformly labelled ${ }^{13} \mathrm{C}-18: 3 n-3\left(\mathrm{U}-{ }^{13} \mathrm{C}-18: 3 n-3\right) / \mathrm{kg}$ body weight (BW) were fed to the pigs to measure the direct oxidation (Ox) of $18: 3 n-3$. For serial slaughter (SS) and whole-body fatty acid composition analyses, the pigs were killed on days 0,15 and $30 . n$ represents the number of observations.

carcass and viscera management for determining the chemical and physical body composition have been outlined in detail previously ${ }^{(7)}$. In short, at slaughter, blood was collected quantitatively, weighed and discarded, whereas visceral organs (kidneys, spleen, liver, lungs and heart) were weighed individually. The full gastrointestinal tract was weighed, emptied and re-weighed to determine gut fill. Thereafter, the individual segments of the gastrointestinal tract (stomach and small and large intestines) were weighed. The empty gastrointestinal tract was added to the visceral organs, placed in a plastic bag and frozen at $-20^{\circ} \mathrm{C}$. The empty carcass (which included head, feet, hair, nails and skin) was weighed, placed in plastic bags and stored at $-20^{\circ} \mathrm{C}$.

Sample preparation and chemical analysis were carried out according to previous procedures in our laboratory ${ }^{(7)}$. Freezedried subsamples (carcass, pooled viscera and diets) were ground and homogenised with liquid $\mathrm{N}_{2}$ in a conventional coffee grinder. Duplicate samples were then used to determine analytical DM content according to the Association of Official Analytical Chemists ${ }^{(10)}$. N content in the diet, carcass, viscera and digesta samples was determined in triplicate utilising an induction furnace and thermal conductivity $\mathrm{N}_{2}$ analyser (Leco FP-528; Leco Corporation). Ash content was determined in duplicate according to the Association of Official Analytical Chemists $^{(10)}$. Crude fat content in the carcass, viscera, diet and digesta samples was determined by extraction using a fat analyser (ANKOM XT20, method 2; Ankom Technology Corporation) without prior acid hydrolysis. Freeze-dried digesta and diet samples were analysed for titanium dioxide content using standard procedures ${ }^{(10)}$.

For fatty acid (FA) analyses, lipids were extracted from the carcass, viscera, diet and digesta samples using chloroformmethanol $(2: 1, \mathrm{v} / \mathrm{v})$ extraction according to the method of Bligh \& Dyer ${ }^{(11)}$ in the presence of the internal standard, tridecanoic acid (13:0; Nu Chek Prep). During sample processing, efforts were made to minimise 13: 0 losses; aliquots of the lipid extract were dried under $\mathrm{N}_{2}$ and subjected to transmethylation using boron trichloride in methanol and heating the methylation tubes in a boiling water-bath ${ }^{(12)}$. The resulting FA methyl esters were analysed on a Varian 3400 gas-liquid chromatograph (Varian) equipped with a $60 \mathrm{~m}$ DB-23 capillary column $(0.32 \mathrm{~mm}$ internal diameter). GLC and FA peak identification procedures have been described previously ${ }^{(13)}$.

\section{Direct measurement of $\alpha$-linolenic acid oxidation}

Uniformly labelled ${ }^{13} \mathrm{C}$ - $\alpha$-linolenic acid ethyl ester ( $>99$ atom\%) was purchased from Cambridge Isotopes Laboratories, Inc. This preparation contained $95 \%$ of $\mathrm{U}^{13} \mathrm{C}-18: 3 n-3$ and other $\mathrm{FA}$ made up the remainder. The oxidation of $\mathrm{U}^{13}{ }^{13} \mathrm{C}-18: 3 n-3$ was measured in the pigs when their BW was approximately $35 \mathrm{~kg}$ in an open-circuit respiration calorimetry system ${ }^{(14)}$, with realtime measurements of air flow and $\mathrm{CO}_{2}$ content in the exhaust air (Qubit Systems). Fresh air was drawn through the system at approximately $50 \mathrm{l} / \mathrm{min}$ using a large air pump (Model 0523-101Q-G588EDX; Gast Manufacturing, Inc.). Exhaust air flow was quantified using an air mass flow meter (Alicat M series; Alicat Scientific, Inc.). After quantification with the air flow meter, the air flow was split into two streams. The small stream (about $1 \%$ of total air flow and controlled by air pump Model F360 and air flow meter Model P650) was used for realtime measurements of $\mathrm{CO}_{2}$ content (Model S155, Infrared $\mathrm{CO}_{2}$ Analyzer; Qubit Systems) at 5s intervals (C407 - Data Acquisition Software version 2.0; Qubit Systems) and for trapping $\mathrm{CO}_{2}$ for subsequent isotopic enrichment analyses. A drierite column was inserted into the small air stream for the removal of water just before the measurement of $\mathrm{CO}_{2}$ content. From the small air stream, $\mathrm{CO}_{2}$ was trapped quantitatively over $0.5 \mathrm{~h}$ periods for $24 \mathrm{~h}$ in a solution of $1 \mathrm{M}-\mathrm{NaOH}$. Background $\mathrm{CO}_{2}$ samples were collected before feeding the tracer dose between -0.5 and $0 \mathrm{~h}$. Containers containing trapped $\mathrm{CO}_{2}$ and $\mathrm{NaOH}$ were immediately re-vacuumed and stored at room temperature until later analysis.

To determine the recovery of $\mathrm{CO}_{2}$ in the respiration system, $\mathrm{CO}_{2}$ was released from a $2 \cdot 24 \mathrm{M}-\mathrm{NaHCO}_{3}$ solution (1 litre) that was placed in the empty respiration system. The quantity of $\mathrm{NaHCO}_{3}$ was chosen to simulate $\mathrm{CO}_{2}$ output from a $50 \mathrm{~kg}$ BW pig over a $2 \mathrm{~h}$ period and consuming approximately $1.8 \mathrm{~kg}$ of feed daily. To release $\mathrm{CO}_{2}, \mathrm{HCl}$ was continuously infused into the solution at $265 \mathrm{ml} / \mathrm{h}$ for $2 \mathrm{~h}$. The recovery of $\mathrm{CO}_{2}$ was 96.9 (sE 1.01$) \%\left(n\right.$ 6), demonstrating complete $\mathrm{CO}_{2}$ recovery.

The pigs were fasted overnight $(9 \mathrm{~h})$ before the direct measurement of $18: 3 n-3$ oxidation. The pigs were placed in the calorimetry system at approximately 07.00 hours, and measurements were started the next day at approximately 07.00 hours. At 07.30 hours, the pigs were fed a single-bolus 
dose of $\mathrm{U}^{13} \mathrm{C}-18: 3 n-3 \quad(10 \mathrm{mg} / \mathrm{kg}$ BW) mixed with $200 \mathrm{~g}$ of the experimental diet. The pigs consumed the tracercontaining feed within $5 \mathrm{~min}$; thereafter, the remainder of the morning meal was given. At 6,12 and $18 \mathrm{~h}$ after the start of $\mathrm{CO}_{2}$ collection, $\mathrm{CO}_{2}$ analysers were calibrated using a two-point calibration using a custom-made span gas containing $4 \% \mathrm{CO}_{2}$ and $\mathrm{N}_{2}$ (grade 4.8 representing $0 \% \mathrm{CO}_{2}$ ) (BOC gas).

Enrichment of $\mathrm{CO}_{2}$ in the exhaust air samples was determined in duplicate for each $0.5 \mathrm{~h}$ period by continuous flow isotope ratio $\mathrm{MS}^{(15)}$. The analyses were carried out at the Department of Earth Sciences, University of Waterloo (200 University Avenue West, Waterloo, ON, Canada N2L 3G1). The $\mathrm{CO}_{2}$ enrichment and whole-body $\mathrm{CO}_{2}$ excretion values were used to estimate the proportion of administered FA that was oxidised and excreted with breath as $\mathrm{CO}_{2}$ over $24 \mathrm{~h}^{(14)}$.

\section{Calculations and statistical analyses}

The apparent ileal digestibility (AID) of the ingested crude fat, $18: 3 n-3$ and linoleic acid (18:2n-6) was calculated as described elsewhere ${ }^{(16)}$, and it is expressed as a percentage.

The RE of $18: 3 n-3$ and $18: 2 n-6$ were calculated as follows:

$$
\text { FA RE }(\%)=(\text { FA retention } / \text { FA intake }) \times 100,
$$

where FA retention represents the difference between the final and initial whole-body $18: 3 n-3$ and $18: 2 n-6$ masses at defined stages of growth; FA intake for each individual FA was also calculated for defined stages of growth.

The AC of $18: 3 n-3$ to $n-3$ HUFA was calculated as follows:

$$
\begin{aligned}
\text { AC of } 18: & 3 n-3 \text { to individual } n-3 \text { HUFA }(\%)=(\%) \\
= & ((\text { individual } n-3 \text { HUFA retention } \\
& - \text { total individual } n-3 \text { HUFA intake }) / \\
& \text { total } 18: 3 n-3 \text { take })) \times 100
\end{aligned}
$$

where individual $n$-3 HUFA retention represents the wholebody retention of $18: 3 n-3$ intermediary products such as stearidonic acid (18:4n-3), eicosatrienoic acid (20:3n-3), eicosatetraenoic acid (20:4n-3), 20:5n-3, docosatetraenoic acid (22:4n-3), 22:5n-3 and $22: 6 n-3$ at defined stages of growth. Similar calculations were used to estimate the AC of 18: $2 n-6$ to individual $n$-6 HUFA (e.g. all $n$-6 PUFA minus $18: 2 n-6)$. The intakes of $18: 3 n-3$ and $18: 2 n-6$ were calculated for the two subsequent $15 \mathrm{~d}$ periods.

The calculated mean disappearance of $18: 3 n-3$ (expressed as a proportion of $18: 3 n-3$ intake), an indirect measure of oxidation, was calculated $^{(14)}$ as follows:

$$
\begin{aligned}
\text { Disappearance of } 18: & 3 n-3(\%)=(\text { AID } 18 \\
: & 3 n-3 \text { intake }-(\operatorname{RE} 18 \\
: & 3 n-3+\text { AC of } 18 \\
: & 3 n-3 \text { to } n-3 \text { HUFA }) / \text { total } 18 \\
: & 3 n-3 \text { intake. }
\end{aligned}
$$

Direct oxidation of $18: 3 n-3$ was calculated from the cumulative recovery of $\mathrm{CO}_{2}$ with $\mathrm{CO}_{2}$ in the exhaust air $24 \mathrm{~h}$ after feeding the tracer, and it is expressed as a proportion of the administered ${ }^{13} \mathrm{C}$ dose from $\mathrm{U}^{13}{ }^{13} \mathrm{C}-18: 3 n-3$. Cumulative recovery was calculated either directly from the air flow measurements and determined $\mathrm{CO}_{2}$ enrichment excess for each $0.5 \mathrm{~h}$ period or from the estimated cumulative $\mathrm{CO}_{2}$ recovery using alternative mathematical functions. No attempt was made to adjust values for the retention of $\mathrm{CO}_{2}$ within bicarbonate pools in the pigs' body and faecal and urinary losses.

To fit the hourly recovery of ${ }^{13} \mathrm{C}$ in the expired air as a percentage of administered ${ }^{13} \mathrm{C}$, four mathematical functions were applied: $\gamma^{(17)}$; Ali \& Schaeffer ${ }^{(18)}$; Wilmink ${ }^{(19)}$; Dijkstra et al. ${ }^{(20)}$. Similarly, to fit the cumulative recovery of ${ }^{13} \mathrm{C}$ in the expired air as a percentage of administered ${ }^{13} \mathrm{C}$, five alternative mathematical growth functions were applied: monomolecular; Gompertz; Richards; Michaelis-Menten; von Bertalanffy ${ }^{(21-23)}$. The Solver Module of Excel (Excel; Microsoft Corporation) was used for the optimisation of numerical algorithms ${ }^{(24)}$. The model with the lowest values of Akaike's information criterion was considered the most appropriate model.

Cumulative FA intake and whole-body FA mass are expressed in $g$ per pig. The various measures of FA utilisation were calculated using pigs as experimental units. For the various response variables, statistical analyses were carried out using ANOVA according to the MIXED procedure of SAS (version 9.2; SAS Institute, Inc.). The pigs were used as a random effect. The effect of litter ( $n$ 8) was first explored as a source of variation, but it was found to be not significant for the various response variables $(P>0 \cdot 10)$ and was therefore removed from the statistical model. Period effects on the RE and AC were assessed using the Tukey-Kramer honestly significant difference test. Linear and quadratic contrast analyses were carried out to assess changes in whole-body chemical components (protein, fat, ash and water) and whole-body FA over time. $P<0.05$ was considered significant, whereas $0.05<P<0.10$ was considered a trend and $P>0.10$ was considered non-significant.

\section{Results} General observations, growth performance and
body composition

The analysed contents of protein, crude fat, $\mathrm{Ca}, \mathrm{P}, \mathrm{Na}, 18: 3 n-3$ and $18: 2 n-6$ and the $18: 2 n-6 / 18: 3 n-3$ ratio in the experimental diets were similar to the anticipated values (Table 1), indicating that the diets were prepared properly. The pigs appeared to be healthy, readily consumed their feed allowances and did not exhibit abnormalities in behaviour. Similarly, no problems were encountered with the direct measurement of $18: 3 n-3$ oxidation using the isotope tracer. Growth performance data (Table 2) can be considered typical for this relatively low level of feed intake ${ }^{(25)}$. Growth rate and feed efficiency were similar between phase I and phase II $(P>0 \cdot 10)$, whereas daily feed intake increased with BW $(P<0 \cdot 002)$ as expected.

Across all the observations, the sum of chemical body constituents (protein, lipid, ash and water) contributed to 99.5 (SE 0.41)\% of empty BW (Table 3), confirming the adequacy of the sampling and analytical procedures.

after feeding the tracer, and it is expressed as a proportion 
Table 2. Growth performance of pigs fed a grower diet containing $10 \%$ ground flaxseed for $30 \mathrm{~d}^{\star}$

\begin{tabular}{lcccc}
\hline Items & Days 0-15 & Days 15-30 & SEM & $P$ \\
\hline Number of pigs & 11 & 5 & & \\
Initial BW (kg) & 28.5 & 36.4 & & \\
Final BW (kg) & 37.9 & 45.7 & & \\
Average daily feed intake (g/d) & 1307 & 1452 & 25.6 & 0.002 \\
Average daily gain (g/d) & 604 & 630 & 38.0 & 0.655 \\
Gain/feed (g/g) & 0.463 & 0.430 & 0.249 & 0.378 \\
\hline
\end{tabular}

BW, body weight.

*Pigs were fed restrictedly at $70 \%$ of the voluntary daily digestible energy intake according to the National Research Council ${ }^{(8)}$. On day 15 , six pigs were killed to determine chemical and physical body composition.

Across the slaughter BW, gut fill represented 5.03 (SE 0.36) \% of live BW. Empty BW and main physical and chemical body component masses increased linearly over time $(P<0 \cdot 01)$. Relationships between body protein, body ash and body water masses were similar across the slaughter BW $(P>0 \cdot 10)$.

\section{Fatty acid mass, apparent ileal digestibility and apparent conversion}

The whole-body content of individual FA including SFA, MUFA, $n-3$ and n-6 PUFA increased linearly over time $(P<0 \cdot 01 ;$ Table 4). Time had no effect on the AID of FA and crude fat $(P>0 \cdot 10)$; across the two digesta sampling times, AID was 77 (sE 3.60)\% for crude fat, 78.2 (sE 3.38) \% for $18: 2 n-6$ and 83.6 (se $2 \cdot 24$ ) \% for $18: 3 n-3$. Expressed as a proportion of intake, RE declined with time (days $0-15 v$. days $15-30)$ for both $18: 3 n-3(68.4 v .52 .6 \% ; P=0.098)$ and 18:2n-6 (107 v. 53.2\%; $P=0.031)$. Similarly, the AC of $18: 3 n-3$ to eicosatrienoic acid ( $20: 3 n-3 ; 7.51 v .4 .05 \%)$, eicosatetraenoic acid $(20: 4 n-3 ; 0.62 v \cdot 0 \cdot 31 \%)$ and $22: 6 n-3(1 \cdot 16$ $v$. $-0.004 \%)$ was reduced over time $(P<0.05$; Fig. 2$)$, whereas that of $18: 3 n-3$ to $20: 5 n-3(1.22 v .0 \cdot 83 \% ; P=0 \cdot 141)$ and
$22: 5 n-3(2.52 v \cdot 1 \cdot 64 \% ; P=0 \cdot 110)$ did not change over time. The AC of $18: 2 n-6$ to $n-6$ HUFA such as $\gamma$-linolenic acid (18:3n-6; $0.34 v \cdot 0 \cdot 05 \%)$, eicosadienoic acid (20:2n-6; 4.66 v. $1.04 \%)$, dihomo- $\gamma$-linolenic acid (20:3n-6; $0.74 v .0 \cdot 16 \%)$, arachidonic acid $(20: 4 n-6 ; 2 \cdot 32$ v. $0 \cdot 18 \%)$, adrenic acid (22: $4 n-6 ; 0.63 v .-0.003 \%)$ and $n-6$ docosapentaenoic acid (22:5n-6; $0.15 v .-0.01 \%)$ was reduced over time $(P<0.05$; Fig. 3). Within the periods, total AC was higher for $n-3$ HUFA than for $n-6$ HUFA ( $13.1 v .6 .9 \%$ and $8.8 v .1 .4 \%$ for days $0-15$ and $15-30$, respectively; $P<0 \cdot 01$; Figs. 2 and 3 ).

\section{Oxidation and disappearance of $\alpha$-linolenic acid}

The appearance of $\mathrm{CO}_{2}$ after feeding the single-bolus dose of $\mathrm{U}^{-13} \mathrm{C}-18: 3 n-3$ is shown in Figs. 4 and 5 for each individual pig. The excretion of ${ }^{13} \mathrm{C}$ in the expired air followed a similar pattern for all the pigs. The enrichment of ${ }^{13} \mathrm{C}$ in the exhaust air (breath $\mathrm{CO}_{2}$ ) was detected $1 \mathrm{~h}$ after the administration of $\mathrm{U}-{ }^{13} \mathrm{C}-18: 3 n-3$ and was found to reach peak levels at $4.5 \mathrm{~h}$ (7.25 (sE 0.95$) \%$ of the total ${ }^{13} \mathrm{C}$ exhaled or 0.554 (SE 0.06$) \%$ administered dose $/ \mathrm{h}$ ) and decrease to approximately half maximum levels by $9 \mathrm{~h}(3.08$ (SE 0.34$) \%$ of the total ${ }^{13} \mathrm{C}$

Table 3. Chemical and physical body composition of growing pigs fed a grower diet containing $10 \%$ ground flaxseed for $30 \mathrm{~d}$

\begin{tabular}{|c|c|c|c|c|c|c|c|}
\hline Items & Day 0 & Day 15 & Day 30 & SEM & $P$ & Linear & Quadratic \\
\hline Number of pigs & 4 & 6 & 5 & & & & \\
\hline Days & $0^{\mathrm{a}}$ & $15 \cdot 8^{\mathrm{b}}$ & $30^{c}$ & 0.566 & $<0.001$ & $<0.001$ & 0.232 \\
\hline Empty BW (kg) & $25 \cdot 1^{a}$ & $37 \cdot 3^{b}$ & $44.1^{\mathrm{c}}$ & 0.717 & $<0.001$ & $<0.001$ & 0.008 \\
\hline PB $(\%)^{*}$ & $16 \cdot 8$ & $17 \cdot 0$ & $17 \cdot 3$ & 0.313 & 0.524 & 0.266 & 0.991 \\
\hline LB $(\%) \dagger$ & $10 \cdot 0^{\mathrm{a}}$ & $13 \cdot 5^{\mathrm{b}}$ & $13 \cdot 3^{b}$ & 0.695 & 0.009 & 0.008 & 0.039 \\
\hline LB/PB & $0.599^{a}$ & $0.798^{b}$ & $0.774^{\mathrm{b}}$ & 0.053 & 0.053 & 0.047 & 0.101 \\
\hline $\mathrm{AB}(\%) \ddagger$ & 2.83 & 2.60 & 2.85 & 0.094 & 0.130 & 0.851 & 0.051 \\
\hline WB $(\%) \S$ & $70 \cdot 3^{a}$ & $66 \cdot 1^{\mathrm{b}}$ & $66 \cdot 1^{\mathrm{b}}$ & 0.485 & $<0.001$ & $<0.001$ & 0.004 \\
\hline WB/PB & $5 \cdot 17$ & 5.08 & $5 \cdot 13$ & 0.068 & 0.652 & 0.729 & 0.388 \\
\hline AB/PB & 0.169 & 0.153 & 0.165 & 0.007 & 0.235 & 0.737 & 0.098 \\
\hline PVisc/PB & $15 \cdot 5^{\mathrm{a}}$ & $11.00^{\mathrm{b}}$ & $10 \cdot 6^{\mathrm{b}}$ & 0.543 & $<0.001$ & $<0.001$ & 0.007 \\
\hline PCar/PB & $80 \cdot 2^{\mathrm{a}}$ & $84 \cdot 6^{\mathrm{b}}$ & $84 \cdot 8^{\mathrm{b}}$ & 0.701 & 0.001 & 0.001 & 0.023 \\
\hline LVis/LB & $9.04^{\mathrm{a}}$ & $5 \cdot 34^{\mathrm{b}}$ & $6 \cdot 15^{\mathrm{b}}$ & 0.327 & $<0.001$ & $<0.001$ & $<0.001$ \\
\hline LCar/LB & $90 \cdot 7^{\mathrm{a}}$ & $94.5^{\mathrm{b}}$ & $93 \cdot 7^{b}$ & 0.331 & $<0.001$ & $<0.001$ & $<0.001$ \\
\hline
\end{tabular}

BW, body weight; PB, body protein; LB, body lipid; AB, body ash; WB, body water; PVisc, viscera protein mass; PCar, carcass protein mass; LVis, viscera lipid mass; LCar, carcass lipid mass.

${ }^{a, b, c}$ Mean values with unlike superscript letters were significantly different $(P<0.05)$

* Whole PB mass, expressed as a percentage of empty BW.

†Whole LB mass, expressed as a percentage of empty BW.

$\ddagger$ Whole $A B$ mass, expressed as a percentage of empty BW.

$\S$ Whole WB mass, expressed as a percentage of empty BW. 
Table 4. Whole-body fatty acid (FA) mass in growing pigs fed a grower diet containing $10 \%$ ground flaxseed for $30 \mathrm{~d}^{\star}$

\begin{tabular}{|c|c|c|c|c|c|c|c|}
\hline Items & Day 0 & Day 15 & Day 30 & SEM & $P$ & Linear & Quadratic \\
\hline Number of pigs & 4 & 6 & 5 & & & & \\
\hline Live BW (kg)† & $26 \cdot 2$ & 39.2 & $45 \cdot 7$ & 0.733 & $<0.001$ & $<0.001$ & 0.001 \\
\hline Empty BW (kg) & $25 \cdot 1^{\mathrm{a}}$ & $37 \cdot 3^{\mathrm{b}}$ & $44 \cdot 1^{\mathrm{c}}$ & 0.717 & $<0.001$ & $<0.001$ & 0.008 \\
\hline Body lipid (\% of empty BW) & $10 \cdot 0^{\mathrm{a}}$ & $13 \cdot 5^{\mathrm{b}}$ & $13 \cdot 3^{b}$ & 0.695 & 0.009 & 0.008 & 0.039 \\
\hline \multicolumn{8}{|l|}{$\begin{array}{l}\text { FA ( } g \text { in empty BW) } \\
\text { SFA }\end{array}$} \\
\hline $14: 0$ & $27 \cdot 6^{a}$ & $48 \cdot 1^{b}$ & $55 \cdot 0^{\mathrm{b}}$ & 4.68 & 0.004 & 0.002 & 0.213 \\
\hline $16: 0$ & $439^{a}$ & $771^{\mathrm{b}}$ & $846^{\mathrm{b}}$ & 69.5 & 0.004 & 0.002 & 0.122 \\
\hline $18: 0$ & $169^{a}$ & $325^{\mathrm{b}}$ & $392^{\mathrm{b}}$ & $45 \cdot 0$ & 0.015 & 0.005 & 0.406 \\
\hline $20: 0$ & $2 \cdot 22^{\mathrm{a}}$ & $4.46^{\mathrm{b}}$ & $4.93^{b}$ & 0.697 & 0.041 & 0.020 & 0.276 \\
\hline $22: 0$ & 0.05 & 0.07 & 0.08 & 0.019 & 0.897 & 0.743 & 0.750 \\
\hline $24: 0$ & 0.06 & 0.05 & 0.07 & 0.244 & 0.812 & 0.854 & 0.545 \\
\hline ¿SFA & $638^{\mathrm{a}}$ & $1148^{\mathrm{b}}$ & $1298^{b}$ & 113 & 0.005 & 0.002 & 0.190 \\
\hline \multicolumn{8}{|l|}{ MUFA } \\
\hline $7 c-14: 1$ & 0.83 & 0.99 & 0.88 & 0.127 & 0.629 & 0.794 & 0.364 \\
\hline $9 c-16: 1$ & 77.9 & 110 & 98.9 & $10 \cdot 2$ & 0.096 & 0.185 & 0.076 \\
\hline $9 c-18: 1$ & $847^{\mathrm{a}}$ & $1561^{\mathrm{b}}$ & $1645^{\mathrm{b}}$ & 111 & $<0.001$ & $<0.001$ & 0.025 \\
\hline $11 c-20: 1$ & $20 \cdot 1^{\mathrm{a}}$ & $33.9^{b}$ & $32 \cdot 5^{\mathrm{a}, \mathrm{b}}$ & 2.89 & 0.010 & 0.013 & 0.036 \\
\hline $13 c-22: 1$ & 0.56 & 0.69 & 0.19 & 0.242 & 0.307 & 0.281 & 0.270 \\
\hline $15 c-24: 1$ & $0.01^{a, b}$ & $0.01^{a}$ & $0.04^{b}$ & 0.012 & 0.249 & 0.336 & $0 \cdot 171$ \\
\hline ¿MUFA & $947^{\mathrm{a}}$ & $1707^{b}$ & $1777^{\mathrm{b}}$ & 120 & $<0.001$ & $<0.001$ & 0.024 \\
\hline \multicolumn{8}{|l|}{$n-6$ PUFA } \\
\hline $18: 2 n-6$ & $261^{\mathrm{a}}$ & $583^{b}$ & $748^{\mathrm{C}}$ & $53 \cdot 7$ & $<0.001$ & 0.001 & 0.084 \\
\hline $18: 3 n-6$ & $1.03^{a}$ & $2.05^{\mathrm{b}}$ & $2 \cdot 22^{b}$ & 0.159 & $<0.001$ & $<0.001$ & 0.028 \\
\hline $20: 2 n-6$ & $11.4^{\mathrm{a}}$ & $25 \cdot 5^{\mathrm{b}}$ & $28 \cdot 7^{\mathrm{b}}$ & 2.63 & $<0.001$ & $<0.001$ & 0.025 \\
\hline $20: 3 n-6$ & $2.55^{\mathrm{a}}$ & $4 \cdot 78^{b}$ & $5 \cdot 29^{b}$ & 0.321 & $<0.001$ & $<0.001$ & 0.019 \\
\hline $20: 4 n-6$ & $7 \cdot 30^{\mathrm{a}}$ & $14 \cdot 6^{\mathrm{b}}$ & $15 \cdot 0^{\mathrm{b}}$ & 0.978 & $<0.001$ & $<0.001$ & 0.005 \\
\hline $22: 4 n-6$ & $2.39^{a}$ & $4 \cdot 31^{b}$ & $4 \cdot 30^{b}$ & 0.341 & 0.002 & 0.002 & 0.021 \\
\hline $22: 5 n-6$ & $0.10^{a}$ & $0.56^{\mathrm{b}}$ & $0.55^{\mathrm{b}}$ & 0.121 & 0.042 & 0.035 & 0.123 \\
\hline$\Sigma n-6$ PUFA & $286^{a}$ & $634^{\mathrm{b}}$ & $804^{c}$ & 54.8 & $<0.001$ & $<0.001$ & 0.069 \\
\hline \multicolumn{8}{|l|}{$n-3$ PUFA } \\
\hline $18: 3 n-3$ & $15 \cdot 2^{\mathrm{a}}$ & $247^{\mathrm{b}}$ & $431^{c}$ & $22 \cdot 6$ & $<0.001$ & $<0.001$ & 0.357 \\
\hline $18: 4 n-3$ & 1.61 & 1.69 & 1.90 & 0.215 & 0.683 & 0.438 & 0.713 \\
\hline $20: 3 n-3$ & $2 \cdot 05^{\mathrm{a}}$ & $27 \cdot 5^{b}$ & $41.5^{\mathrm{c}}$ & $2 \cdot 71$ & $<0.001$ & $<0.001$ & 0.135 \\
\hline $20: 4 n-3$ & $0.50^{\mathrm{a}}$ & $2 \cdot 65^{\mathrm{b}}$ & $3 \cdot 75^{\mathrm{c}}$ & 0.301 & $<0.001$ & $<0.001$ & 0.135 \\
\hline $20: 5 n-3$ & $0.717^{a}$ & $4 \cdot 86^{b}$ & $7.55^{\mathrm{c}}$ & 0.582 & $<0.001$ & $<0.001$ & 0.350 \\
\hline $22: 5 n-3$ & $1.67^{\mathrm{a}}$ & $10 \cdot 2^{b}$ & $16 \cdot 0^{c}$ & $1 \cdot 14$ & $<0.001$ & $<0.001$ & 0.291 \\
\hline $22: 6 n-3$ & $2 \cdot 39^{\mathrm{a}}$ & $6 \cdot 45^{\mathrm{b}}$ & $6.50^{\mathrm{b}}$ & 0.632 & $<0.001$ & $<0.001$ & 0.015 \\
\hline$\sum n-3$ PUFA & $24 \cdot 2^{\mathrm{a}}$ & $300^{\mathrm{b}}$ & $509^{c}$ & $26 \cdot 9$ & $<0.001$ & $<0.001$ & 0.273 \\
\hline$\sum n-6$ PUFA $/ n-3$ PUFA & $11 \cdot 8^{a}$ & $2 \cdot 11^{\mathrm{b}}$ & $1.59^{\mathrm{c}}$ & 0.156 & $<0.001$ & $<0.001$ & $<0.001$ \\
\hline ¿PUFA & $310^{\mathrm{a}}$ & $935^{\mathrm{b}}$ & $1313^{c}$ & $93 \cdot 6$ & $<0.001$ & $<0.001$ & 0.115 \\
\hline ¿Analysed FA & $1894^{a}$ & $3791^{b}$ & $4388^{b}$ & 278 & $<0.001$ & $<0.001$ & 0.058 \\
\hline
\end{tabular}

BW, body weight.

a,b,c Mean values with unlike superscript letters were significantly different $(P<0.05)$

${ }^{*}$ Pigs were fed a common diet for $30 \mathrm{~d}$. Cumulative 18:2n-6 intakes for days 0-15, 15-30 and 0-30 were 299 (SE 4.42), 302 (SE 21.6) and 567 (SE 16.4) g/pig, respectively, whereas cumulative $18: 3 n-3$ intakes for days $0-15,15-30$ and 30 were 339 (SE $5 \cdot 01$ ), 343 (SE 24.5) and 643 (SE 18.6) g/pig, respectively.

† Live BW.

exhaled or 0.247 (SE 0.04$) \%$ administered dose/h). At $15 \mathrm{~h}$, $95 \cdot 2$ (sE 2.61) \% of the $24 \mathrm{~h}$ cumulative expired ${ }^{13} \mathrm{C}$ was recovered. Between 15 and $17 \mathrm{~h}$, the enrichment of ${ }^{13} \mathrm{C}$ in the exhaust air returned to baseline levels for all the pigs. Based on Akaike's information criterion (Table 5), the Dijkstra function was the best mathematical function to fit the hourly ${ }^{13} \mathrm{C}$ recovery in the exhaust air (Fig. 4), whereas the Richards function was the most appropriate function to represent the cumulative recovery of ${ }^{13} \mathrm{C}$ in the exhaust air as a function of time (Fig. 5). The estimated cumulative oxidation of $\mathrm{U}^{-13} \mathrm{C}-18: 3 n-3$ according to the Richards, Gompertz, Michaelis-Menten, von Bertalanffy and monomolecular functions was 7.88 (SE 0.97), 7.89 (SE 0.98), 7.77 (SE 0.95), 7.88 (SE 0.98$)$ and $7.67(0.93) \%$, respectively, whereas the directly determined cumulative recovery of $\mathrm{CO}_{2}$ in the exhaust air
$24 \mathrm{~h}$ after feeding the tracer was 7.91 (SE 0.98)\%, ranging from $5 \cdot 14$ to $9 \cdot 68 \%$ between the pigs.

Based on the mass balance approach, the calculated disappearance of $18: 3 n-3$ tended to increase over time (2.0 $v .23 .7 \%$ of the available intake; $P=0.07)$. The calculated disappearance of $18: 3 n-3$ over the entire $30 \mathrm{~d}$ period $(8.81$ ( $\mathrm{SE} 5 \cdot 24) \%$ ) was similar to the value obtained with the direct oxidation method.

\section{Discussion}

The purpose of the present study was to determine changes over time in the RE of $18: 3 n-3$ and its AC to $20: 5 n-3$, $22: 5 n-3$ and $22: 6 n-3$ and intermediary $n-3$ HUFA metabolites on a whole-body basis in growing pigs fed a diet containing 


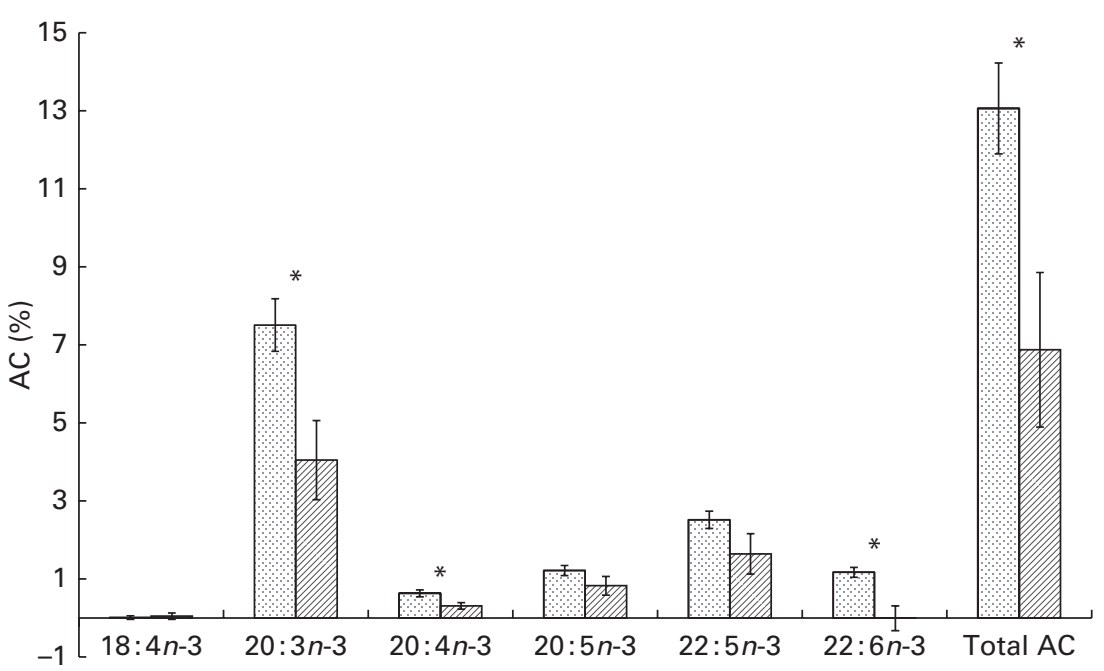

Fig. 2. Apparent conversion (AC) of $\alpha$-linolenic acid to $18: 4 n-3$, stearidonic acid; $20: 3 n-3$, eicosatrienoic acid; $20: 4 n-3$, eicosatetraenoic acid; $20: 5 n-3$, EPA; $22: 5 n-3$, docosapentaenoic acid; and $22: 6 n-3$, DHA, during different time periods (days $0-15$ ( $\square$ ) and $15-30$ ( $\square$ )) in growing gilts fed a grower diet containing $10 \%$ ground flaxseed for $30 \mathrm{~d}$. * Values were significantly different between days $0-15$ and days $15-30(P<0.05)$.

$10 \%$ FS. Using the serial slaughter technique, measurements were made over two consecutive $15 \mathrm{~d}$ periods. Moreover, the oxidation of $18: 3 n-3$ was determined using both a direct isotope method and a mass balance approach (e.g. calculated disappearance). In previous studies, the effect of feeding diets containing either 1.44 or $13.5 \mathrm{~g} / \mathrm{kg} 18: 3 n-3$ on whole-body RE was determined in weanling pigs ( 14 or $21 \mathrm{~d}$ old) raised in two environments (segregated and non-segregated early weaning) without determining the AC of $18: 3 n-3$ to $n-3 \mathrm{HUFA}^{(6)}$. Similarly, Kloareg et al. ${ }^{(26)}$ determined the RE of $18: 3 n-3$ and its AC to $n$-3 HUFA in pigs weighing between 90 and $150 \mathrm{~kg}$ BW and consuming a diet containing $1.5 \mathrm{~g} / \mathrm{kg} 18: 3 n-3$. In these two studies, the AID of $18: 3 n-3$ was not determined.

The design of the present experiment is in contrast to that of human studies in which no attempt was made to adapt the subjects to the experimental diet before determining the oxidation of $18: 3 n-3^{(27-29)}$. Moreover, in most of the human studies, breath is not sampled continuously ${ }^{(27,30)}$. The latter can lead to inaccuracies in the estimates of $\mathrm{CO}_{2}$ production, and consequently FA oxidation, especially when breath is sampled during periods that are less than $5 \mathrm{~min}$ in duration and at 2 or $3 \mathrm{~h}$ intervals ${ }^{(29,31)}$.

\section{Retention efficiency and apparent conversion of n-3 fatty acids}

In the present study, the whole-body masses of SFA, MUFA, and $n-3$ and $n-6$ PUFA increased over time in the pigs when fed modest amounts of FS. These results are in agreement with those of other studies in which the contents of SFA,

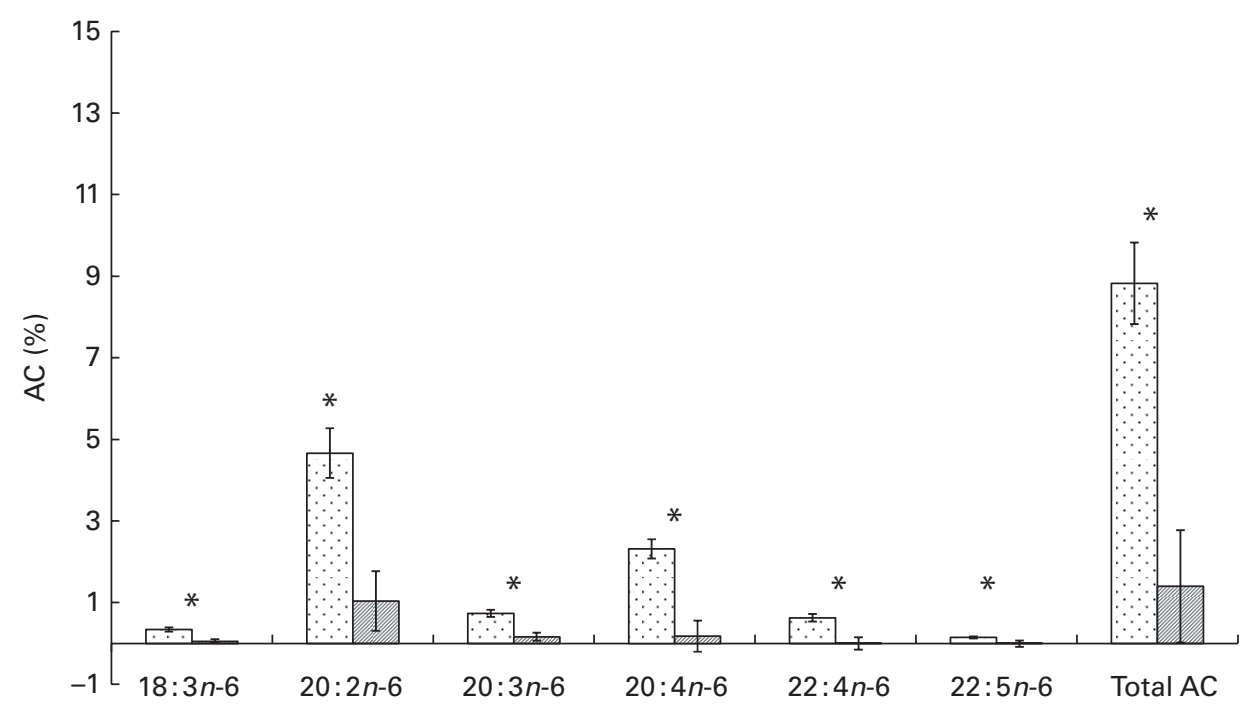

Fig. 3. Apparent conversion (AC) of linoleic acid to $18: 3 n-6, \gamma$-linoleic acid; $20: 2 n-6$, eicosadienoic acid; $20: 3 n-6$, dihomo- $\gamma$-linoleic acid; $20: 4 n-6$, arachidonic acid; $22: 4 n-6$, adrenic acid; and $22: 5 n-6$, docosapentaenoic acid, during different time periods (days $0-15$ ( $\square$ ) and $15-30$ ( $\square$ )) in growing gilts fed a grower diet containing $10 \%$ ground flaxseed for $30 \mathrm{~d}$. * Values were significantly different between days $0-15$ and days $15-30(P<0.05)$. 


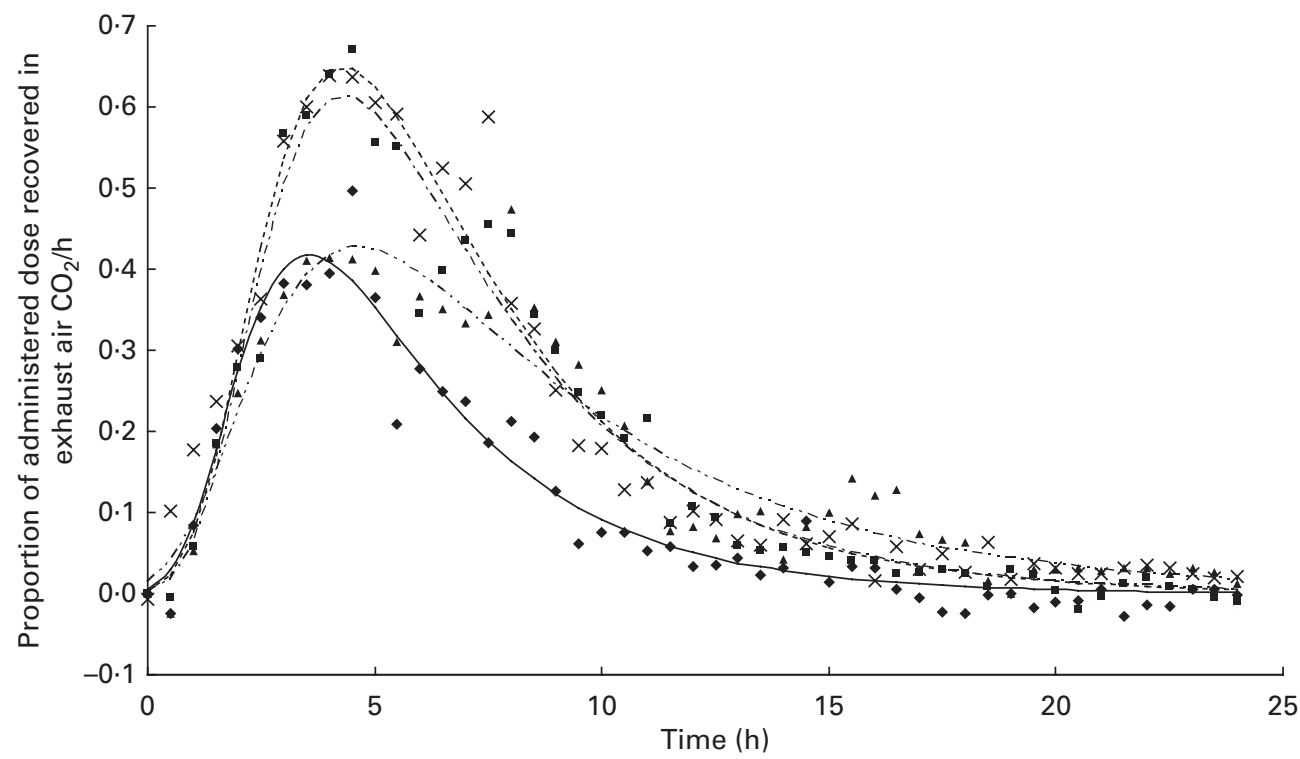

Fig. 4. Hourly ${ }^{13} \mathrm{C}$ recovery in the exhaust air expressed as a proportion of the administered tracer dose of uniformly labelled ${ }^{13} \mathrm{C}$ - $\alpha$-linolenic acid $24 \mathrm{~h}$ immediately following the oral administration of a single bolus of the tracer to growing gilts that were fed a grower diet containing $10 \%$ flaxseed ( $n$ 4). Oxidation study was conducted on day 12 of feeding the experimental diets. The Dijkstra ${ }^{(20)}$ function used to fit the present data set was as follows: $Y=a \times \exp (k 1 \times(1-\exp \{-k 2 \times t\}) / k 2-c \times t)$, where ' $a$ ', ' $c$ ' and ' $t$ ' represent the theoretical initial $\mathrm{CO}_{2}$ production at time ' 0 ', rate of disappearance of ${ }^{13} \mathrm{C}$ in the exhaust air (per $\mathrm{h}$ ) and time since the start of sample collection, respectively, whereas $k 1$ and $k 2$ represent the rate of ${ }^{13} \mathrm{C}$ production and the

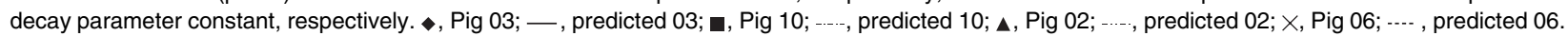

MUFA, and $n$ - 3 and $n-6$ PUFA in specific pork tissues ${ }^{(2,32,33)}$ or in pigs' whole body ${ }^{(6)}$ increased over time when feeding FS-containing diets. In general, the whole-body masses of $n-3$ or $n-6$ PUFA are proportional to dietary $n-3$ or $n-6$ PUFA intakes.

In the present study, the RE of $18: 3 n-3$ in pigs weighing between 27 and $45 \mathrm{~kg} \mathrm{BW}$ was approximately 58.7\%, whereas Kloareg et al. ${ }^{(26)}$ observed that the RE of $18: 3 n-3$ in pigs weighing between 90 and $150 \mathrm{~kg}$ BW was 42.4\%, much lower than that observed in the present study. In younger pigs aged between 14 and $49 \mathrm{~d}$, Bazinet et al. ${ }^{(6)}$ observed that the RE of $18: 3 n-3$ in pigs fed high $18: 3 n-3(13 \cdot 5 \mathrm{~g} / \mathrm{kg})$ content varied between 60 and $84 \%$ of total $18: 3 n-3$ intake. The latter suggests that the RE of $n-3$ PUFA decreases with age and BW. However, the dietary levels and cumulative intake of $18: 3 n-3$, or whole-body $18: 3 n-3$ content, may also affect the RE of $n-3$ PUFA. Additional observations are required to be made to further investigate this phenomenon in growing pigs.

In pigs weighing between 90 and $150 \mathrm{~kg} \mathrm{BW}$ and consuming low amounts of $18: 3 n-3$, the whole-body AC of $18: 3 n-3$ to $n-3$ HUFA was found to be approximately $15 \%{ }^{(26)}$, which was similar to that observed in the present study. In other studies, the AC of $18: 3 n-3$ to $n$ - 3 HUFA in blood was measured using isotope tracers $\left({ }^{14} \mathrm{C}-,{ }^{13} \mathrm{C}-\right.$ or $\left.{ }^{2} \mathrm{H}-18: 3 n-3\right)$ and at one point in time; in these studies, the effects of the level and duration of feeding $18: 3 n-3$ on the RE and AC of $18: 3 n-3$ to $n-3$ HUFA over time were not explored $^{(27,34,35)}$. In the present study, the AC of $18: 3 n-3$ to $n-3$ HUFA was largest for $20: 3 n-3$, followed by $22: 5 n-3$ and $20: 5 n-3$, respectively. The latter is in contrast to that observed in human studies and, based on observations in blood, indicates that $20: 5 n-3$ and then $22: 5 n-3$ are the main HUFA derived from $18: 3 n-3^{(27,36)}$. It can be argued that $n-3$ PUFA profiles in blood do not represent whole-body $n-3$ PUFA profiles ${ }^{(37-39)}$; therefore, measurements based on blood $n$-3 PUFA profiles should be interpreted with caution.

Relatively few experiments ${ }^{(32,33)}$ have reported increasing contents of $20: 3 n-3$ in tissues after feeding FS to pigs. Moreover, to our knowledge, the AC of $18: 3 n-3$ to $20: 3 n-3$ in mammals has not been reported in the literature. In the present experiment, $20: 3 n-3$ was the largest contributor to total $n$-3 HUFA in the body ( $8 \%$ ), which deserves further attention. Pigs fed FS appear unique in their ability to elongate $18: 3 n-3$ to $20: 3 n-3$ via chain elongation process, which differs from previous views of FA metabolism ${ }^{(40)}$. In mammals, $20: 3 n-3$ is generally considered to be an end product of $n-3$ PUFA metabolism, in part because its conversion to $20: 4 n-3$ has not been unequivocally established ${ }^{(41)}$. Recently, it has been determined that $\Delta 8$-desaturate is rather active in mammals and is able to convert $20: 3 n-3$ to $20: 4 n-3^{(42)}$, which in turn can enter the Sprecher pathway. This is of particular interest because $20: 3 n-3$ can help to maintain an adequate supply of $n$ - 3 HUFA for physiologically active eicosanoids and different membrane structures. Whether this alternative pathway is highly active in pigs deserves further investigation.

In agreement with studies involving human subjects and small mammals ${ }^{(27,43)}$, the AC of $18: 3 n-3$ to $22: 6 n-3$ was low in the present study. It has been suggested that the initial conversion of $18: 3 n-3$ to stearidonic acid $(18: 4 n-3)$ by the action of $\Delta 6$-desaturase and the conversion of $20: 4 n-3$ to $20: 5 n$-3 by the action of $\Delta 5$-desaturase are the two main rate-limiting reactions in the Sprecher pathway ${ }^{(40)}$. 


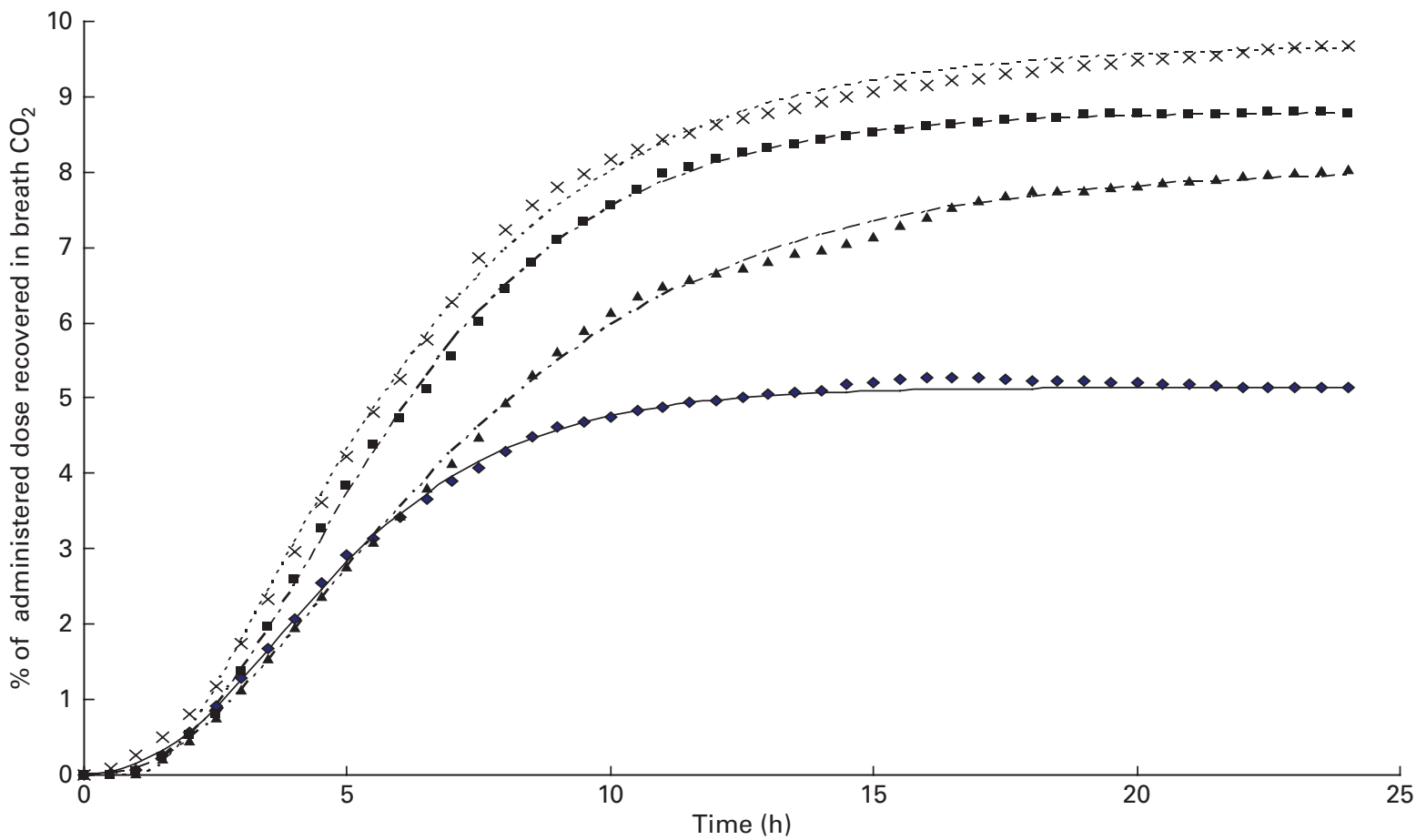

Fig. 5. Cumulative ${ }^{13} \mathrm{C}$ recovery in the exhaust air expressed as a proportion of the administered tracer dose of uniformly labelled ${ }^{13} \mathrm{C}-\alpha$-linolenic acid over $24 \mathrm{~h}$ following administration at hour $0(n 4)$. Growing gilts were fed a grower diet containing $10 \%$ flaxseed for $30 \mathrm{~d}$. Oxidation study was conducted on day 12 of feeding the experimental diets. The Richards function used to fit the present data set was as follows: $Y=A+(H-A) /(1+t \times \exp [-B \times\{x-M\}])^{(1 / t)}$, where ' $A$ ', ' $H$ and ' $B$ ' represents the initial ${ }^{13} \mathrm{C}$ concentration, final ${ }^{13} \mathrm{C}$ concentration and ${ }^{13} \mathrm{C}$ production rate, whereas ' $P$ ' and ' $M$ ' are constants representing the asymptote

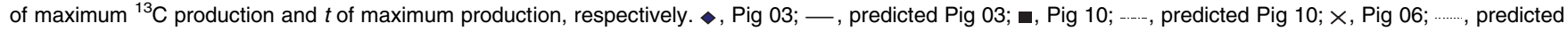
Pig 06; $\mathbf{\Lambda}$, Pig 02; -...., predicted Pig 02. (A colour version of this figure can be found online at http://www.journals.cambridge.org/bjn).

However, based on feeding $18: 4 n-3$ and $20: 5 n-3$ to human subjects, it has been shown that the concentrations of both $20: 5 n-3$ and $22: 5 n-3$ in plasma phospholipids can be increased and that no significant change occurs in the concentration of $22: 6 n-3^{(44,45)}$. The latter suggests that the main constraint for the appearance of $22: 6 n-3$ occurs after the synthesis of $22: 5 n-3$, which supports the lower content of $22: 6 n-3$ than of $22: 5 n-3$ in body fat in the present experiment. These results suggest that the potential rate-limiting reactions, involving the conversion of $22: 5 n-3$ to $22: 6 n-3$, might be found in the last steps of the pathway and in the conversion via the intermediary tetracosapentaenoic acid $(24: 5 n-3)$. This is consistent with the observation that $22: 6 n-3$ cannot be synthesised from $22: 5 n-3$ in the heart of rats, due to the absence of elongase- 2 expression, which is critical for the conversion of $22: 5 n-3$ to $24: 5 n-3^{(46)}$. While elongase- 5 , which elongates FA that are sixteen to twenty-two carbons long, is regulated by PPAR (PPAR $\alpha$ ), elongase- 2 is regulated by sterol regulatory element-binding protein- ${ }^{(46)}$. These two different genetic control mechanisms might explain the tissue-selective conversion of $18: 3 n-3$ to $22: 6 n-3$ and other n-3 PUFA metabolites.

The observed reduction in the AC of $18: 3 n-3$ to $n-3$ HUFA with the duration of feeding $18: 3 n-3$ has not been fully explored. Matsuzaka et $a l^{(47)}$ demonstrated that the expression of $\Delta 6$-desaturase and $\Delta 5$-desaturase mRNA in rat hepatocytes, controlled by sterol regulatory element-binding protein-1, decreased over time in the presence of $18: 2 n-6$; similar but smaller effects were observed in the presence of $20: 5 n-3,22: 5 n-3$ or $22: 6 n-3$, whereas feeding a fat-free diet, stearic acid or oleic acid did not affect the expression of these desaturases. The latter suggests that feeding $18: 2 n$ 6 or $18: 3 n-3$ might, over time, reduce the AC of $18: 3 n-3$ to $n-3$ HUFA and that $n-3$ HUFA, in turn, can down-regulate the expression of $\Delta 6$-desaturase, $\Delta 5$-desaturase and elongase-2. This is consistent with the observed reduction over time in the AC of both $18: 3 n-3$ and $\mathrm{LA}$ to their metabolites in the present study.

According to Sprecher et $a l^{(40)}, n-3$ and $n-6$ FA share a common pathway for their elongation and desaturation, implying interdependence of the metabolism of these two PUFA groups. In the present experiment, equal amounts of $n-3$ and $n-6$ PUFA were included in the diets, which resulted in higher rates of AC of $n-3$ PUFA than of $n-6$ PUFA. Similar results were obtained by others ${ }^{(43,48)}$. In the present study, $18: 3 n-3$ appears to be a stronger suppressor of $n-6$ HUFA conversion than $18: 2 n-6$ is of $n-3$ HUFA conversion.

\section{Oxidation of $\alpha$-linolenic acid}

In the present study, the direct measurement of oxidation, using isotope tracers, and the mass balance approach (calculated disappearance, indirect means to estimate oxidation) yielded very similar estimates of $18: 3 n-3$ oxidation, which suggests that both methods may be suitable to assess the oxidation of $18: 3 n-3$ in growing pigs. 
Table 5. Mean square prediction error (MSPE) ${ }^{\star}$ and Akaike's information criterion (AIC) $\dagger$ values for alternative mathematical functions to represent either cumulative or hourly excretion of $\mathrm{CO}_{2}$ in the expired air following the ingestion of a bolus of uniformly labelled ${ }^{13} \mathrm{C}-18: 3 n-3\left(\mathrm{U}-{ }^{13} \mathrm{C}-18: 3 n-3\right)$ for individual pigs (Figs. 3 and 4$)$

\begin{tabular}{|c|c|c|c|c|c|}
\hline \multirow[b]{2}{*}{ Model } & & \multicolumn{4}{|c|}{ Pig } \\
\hline & & 2 & 3 & 6 & 10 \\
\hline \multicolumn{6}{|c|}{$\begin{array}{l}\text { Hourly excretion of } \mathrm{CO}_{2} \text { in the expired air expressed as a proportion of the administered } \\
\text { dose of tracer }\end{array}$} \\
\hline Dijkstra & MSPE & $\begin{array}{l}0.002 \\
-104.7\end{array}$ & $\begin{aligned} & 0.001-100 \\
&-139.9\end{aligned}$ & $\begin{array}{r}0.002 \\
-104.0\end{array}$ & $\begin{array}{l}0.002 \\
-109.7\end{array}$ \\
\hline Gamma & MSPE & $\begin{array}{c}0.003 \\
-85.00\end{array}$ & $\begin{array}{l}0.003 \\
-94.12\end{array}$ & $\begin{array}{r}0.006 \\
-54.09\end{array}$ & $\begin{array}{r}0.007 \\
-45.40\end{array}$ \\
\hline Wilmink & $\begin{array}{l}\text { MSPE } \\
\text { AIC }\end{array}$ & $\begin{array}{r}0.004 \\
-67 \cdot 35\end{array}$ & $\begin{array}{r}0.006 \\
-50.08\end{array}$ & $\begin{array}{c}0.012 \\
-17 \cdot 90\end{array}$ & $\begin{array}{r}0.011 \\
-24 \cdot 20\end{array}$ \\
\hline Ali-Schaeffer & $\begin{array}{l}\text { MSPE } \\
\text { AIC }\end{array}$ & $\begin{array}{l}0.002 \\
-96.42\end{array}$ & $\begin{array}{l}0.002 \\
-105 \cdot 8\end{array}$ & $\begin{array}{l}0.006 \\
-54.02\end{array}$ & $\begin{aligned} & 0.005 \\
- & 61.70\end{aligned}$ \\
\hline \multicolumn{6}{|c|}{$\begin{array}{l}\text { Cumulative excretion of } \mathrm{CO}_{2} \text { in the expired air expressed as a proportion of the } \\
\text { administered dose of tracer }\end{array}$} \\
\hline Richards & $\begin{array}{l}\text { MSPE } \\
\text { AIC }\end{array}$ & $\begin{array}{r}0.009 \\
-30 \cdot 84\end{array}$ & $\begin{aligned} & 0.005 \\
&-59.80\end{aligned}$ & $\begin{array}{r}0.019 \\
2.874\end{array}$ & $\begin{array}{r}0.004 \\
-72 \cdot 16\end{array}$ \\
\hline Gompertz & $\begin{array}{l}\text { MSPE } \\
\text { AIC }\end{array}$ & $\begin{array}{r}0.020 \\
6.463\end{array}$ & $\begin{aligned} & 0.005 \\
&-56.97\end{aligned}$ & $\begin{array}{c}0.034 \\
33.02\end{array}$ & $\begin{array}{r}0.007 \\
-44.49\end{array}$ \\
\hline Michaelis-Menten & $\begin{array}{l}\text { MSPE } \\
\text { AIC }\end{array}$ & $\begin{array}{l}0.025 \\
18.21\end{array}$ & $\begin{aligned} & 0.016 \\
- & 4.80\end{aligned}$ & $\begin{array}{l}0.025 \\
18 \cdot 21\end{array}$ & $\begin{array}{c}0.024 \\
15.85\end{array}$ \\
\hline Monomolecular & $\begin{array}{l}\text { MSPE } \\
\text { AIC }\end{array}$ & $\begin{array}{c}0.435 \\
155.9\end{array}$ & $\begin{array}{ll}0.190 \\
115.3\end{array}$ & 0.535 & $\begin{aligned} 0.666 \\
176.8\end{aligned}$ \\
\hline von Bertalanffy & $\begin{array}{l}\text { MSPE } \\
\text { AIC }\end{array}$ & $\begin{array}{c}0.009 \\
-32.62\end{array}$ & $\begin{array}{r}0.005 \\
-60.77\end{array}$ & $\begin{array}{r}0.0 \\
0.019 \\
4.120\end{array}$ & $\begin{array}{c}0.004 \\
-73.18\end{array}$ \\
\hline
\end{tabular}

The appearance of ${ }^{13} \mathrm{C}$ in the exhaust air, and thus oxidation of $18: 3 n-3$, followed similar patterns when compared with those observed in human studies ${ }^{(28,29,31)}$. In the present study, several alternative mathematical functions were used to fit the patterns of hourly and actual cumulative $\mathrm{CO}_{2}$ excretion following the oral administration of a bolus dose of $\mathrm{U}^{13} \mathrm{C}-18: 3 n-3$. A detailed discussion of the biological meaning of parameters in these mathematical functions has been published elsewhere ${ }^{(20-22,49)}$. Based on Akaike's information criterion, the Dijkstra function was the best mathematical function to fit the hourly ${ }^{13} \mathrm{C}$ recovery in the exhaust air (Fig. 4). Because of the complexity of the data set, the $\gamma$, Wilmink and Ali-Schaeffer functions were not sufficiently flexible to represent the hourly recovery of $\mathrm{CO}_{2}$. Furthermore, various growth functions accurately fit the cumulative recovery of $\mathrm{CO}_{2}$ (Fig. 5 and Table 5). Although the estimated cumulative oxidation of $18: 3 n-3$ was identical for the Richards, Gompertz and von Bertalanffy functions, Akaike's information criterion values indicated that the Richards and von Bertalanffy functions were the most suitable mathematical functions to represent the actual cumulative oxidation pattern observed in the present study (Fig. 5). These results indicate that the estimated cumulative oxidation of $18: 3 n-3$, using the mathematical models, compared quite closely to the actual cumulative oxidation of $18: 3 n-3$. Modelling patterns of hourly and actual cumulative $\mathrm{CO}_{2}$ excretion will help us to assess the dynamics of $18: 3 n-3$ oxidation in growing pigs and can provide an accurate estimate of the partitioning of $18: 3 n-3$ towards oxidation.
The observed oxidation of $18: 3 n-3$ appears to be lower in the present study (approximately 8\%) when compared with observations in other mammalian species, including adult humans ${ }^{(28,36,50)}$. In human studies ${ }^{(27,36)}$, the oxidation of $18: 3 n-3$ accounts for $20-38 \%$ of the administrated tracer dose during $24 \mathrm{~h}$. The oxidation of $18: 3 n-3$ in guinea pigs was found to be approximately $40 \%{ }^{(5)}$, whereas in rats it was found to range between 60 and $78 \%$ of the administrated dose $^{(4,43)}$. Differences among studies might be related to inherent factors such as age of subjects, adaptation to the experimental diet, sex, body composition and rates of body fat gain $^{(51-54)}$. These highly variable results highlight the need to better understand animal and dietary factors that influence $18: 3 n-3$ utilisation in growing pigs and other species. Moreover, the experimental methodology should also be considered carefully, including between-animal variability and analytical procedures to quantify FA contents in diets and animal tissues. Using deuterated palmitic acid as an indicator of FA oxidation, Westerterp et al. ${ }^{(54)}$ determined that the oxidation of dietary fat was inversely related to body fatness $(r-0.66)$. As growing pigs have a higher capacity for lipid deposition $(<200 \mathrm{~g} / \mathrm{d})^{(6)}$ and body fatness $(13.5 \%$ of body fatness; Table 3) than adult humans, the lower oxidation rate of $18: 3 n-3$, observed in the present experiment, appears to be consistent with the results of Westerterp et al. ${ }^{(54)}$

In the present study, feeding $15.5 \mathrm{~g} / \mathrm{kg}$ of $18: 3 n-3$ to pigs during a $30 \mathrm{~d}$ period induced increasing rates of oxidation of 18:3n-3 over time. To our knowledge, quantitative information concerning the increasing rates of oxidation of 
$18: 3 n-3$ with age is not available for either pigs or humans. Data on the incorporation of $18: 3 n-3$ in select tissues of pigs fed $15 \%$ FS for $7,15,21$ and $28 \mathrm{~d}$ before slaughter at $136 \mathrm{~kg}$ BW appear consistent with the findings of the present study $^{(2)}$. In the present study, it was observed that the incorporation of $18: 3 n-3$ in pork loin was quite efficient during the first 2 weeks of feeding FS; thereafter, the incremental incorporation of $18: 3 n-3$ diminished, suggesting that the oxidation of $n-3$ PUFA increases over time or increases with increasing whole-body $n-3$ PUFA content. The latter is an important nutritional phenomenon that has not been fully explored in both animal and human studies. It appears that when feeding constant increased dietary levels of $n$-3 PUFA, and $18: 3 n-3$ in particular, the oxidation of $n-3$ PUFA increases over time. Whether there is a particular time period during pigs' development when the RE and $\mathrm{AC}$ of $18: 3 n-3$ to $n-3$ HUFA are more efficient, as well as the effect of whole-body FA composition on the RE and AC of $18: 3 n-3$, remains to be explored further.

In conclusion, on a whole-body basis, the $\mathrm{RE}$ and $\mathrm{AC}$ of dietary $18: 3 n-3$ to $n-3$ HUFA decreases with the duration of feeding a diet containing $15 \cdot 5 \mathrm{~g} / \mathrm{kg}$ of $18: 3 n-3$ to growing pigs with a low initial whole-body $n$-3 PUFA content. Direct measures of $18: 3 n-3$ oxidation $(7.91 \%$ of tracer dose; based on feeding a single bolus of labelled $18: 3 n-3)$ and indirect estimates of $18: 3 n-3$ oxidation ( $8.81 \%$ disappearance of intake; based on mass balance) yield similar values; these values are lower in pigs when compared with those in other mammalian species. Feeding modest amounts of $18: 3 n-3$ leads to a significant increase in the content of $20: 5 n-3$, $22: 5 n-3$ and $22: 6 n-3$ in the pigs' body, thus providing health benefits to $n$-3 PUFA-enriched pork consumers. Pigs appear to be unique in that they elongate and store $20: 3 n-3$, an intermediate between $18: 3 n-3$ and $20: 5 n-3$, which deserves to be explored further.

\section{Acknowledgements}

The authors thank J. Zhu, D. T. Woods, G. Vandervoort, A. Rakhshandeh, M. Hansel and L. Trouten-Radford for providing technical assistance. They also thank Dr B. Holub (emeritus professor of the Department of Human Health and Nutritional Sciences, University of Guelph) for contributing to the discussions and interpretation of the results.

The present study was supported by the Ontario Ministry of Agriculture Food and Rural Affairs, Ontario Pork, and NSERC. The funders had no role in the design, analysis of the data, and interpretation of the findings of the study or in the writing of this article.

The authors' contributions are as follows: H. R. M.-R. and C. F. M. d. L. conducted the experiment and had the primary responsibility of the final content of the manuscript; J. P. C. assisted in the modelling part of the manuscript; A. K. S. and J. L. A. were responsible for teaching the use of the calorimetric equipment; C. F. M. d. L chaired all the meetings; all the authors contributed to the manuscript concept and result interpretation, wrote parts of the draft version, critically revised the manuscript, and read and approved the final version.
H. R. M.-R. is a postdoctoral fellow from the University of Guelph and C. F. M. d. L., J. P. C. and J. L. A. are professors at the Department of Animal and Poultry Science of the University of Guelph. H. R. M.-R. and C. F. M. d. L. received reimbursement for their travel and accommodation costs incurred attending the related meetings.

The authors declare that they have no conflicts of interest to declare.

\section{References}

1. Li Z, Kaplan ML \& Hachey DL (2000) Hepatic microsomal and peroxisomal docosahexaenoate biosynthesis during piglet development. Lipids 35, 1325-1333.

2. Romans JR, Johnson RC, Wulf DM, et al. (1995) Effects of ground flaxseed in swine diets on pig performance and on physical and sensory characteristics and omega-3 fatty acid content of pork: II. Duration of feeding $15 \%$ dietary flaxseed. J Anim Sci 73, 1987-1999.

3. Miller MF, Shackelford SD, Hayden KD, et al. (1990) Determination of the alteration in fatty acid profiles, sensory characteristics and carcass traits of swine fed elevated levels of monounsaturated fats in the diet. J Anim Sci $\mathbf{6 8}$, $1624-1631$.

4. Leyton J, Drury PJ \& Crawford MA (1987) Differential oxidation of saturated and unsaturated fatty acids in vivo in the rat. BrJ Nutr 57, 383-393.

5. Fu Z \& Sinclair JA (2000) Novel pathway of metabolism of $\alpha$-linolenic acid in the guinea pig. Pediatr Res 47, 414-417.

6. Bazinet RP, McMillan EG, Seebaransingh R, et al. (2003) Whole-body beta-oxidation of $18: 2 n-6$ and $18: 3 n-3$ in the pig varies markedly with weaning strategy and dietary 18: 3n-3. J Lipid Res 44, 314-319.

7. Martínez-Ramírez HR, Jeaurond EA \& de Lange CFM (2008) Dynamics of body protein deposition and changes in body composition after sudden changes in amino acid intake: I. Barrows. J Anim Sci 86, 2156-2167.

8. Nutrient NRC (1998) Requirements of Swine, 10th rev. ed. Washington, DC: National Academy Press.

9. Jeaurond EA, Rademacher M, Pluske JR, et al. (2008) Impact of feeding fermentable proteins and carbohydrates on growth performance, gut health and gastrointestinal function of newly weaned pigs. Can J Anim Sci 88, 271-281.

10. AOAC (1997) Official Methods of Analysis, 16th ed. Washington, DC: Association of Official Analytical Chemists.

11. Bligh EG \& Dyer WJ (1959) A rapid method of total lipid extraction and purification. Can J Biochem Physiol 37, 911-917.

12. Morrison WR \& Smith LM (1964) Preparation of fatty acid methyl esters and dimethylacetals from lipids with boron fluoride methanol. J Lipid Res 5, 600-608.

13. Stark KD \& Holub BJ (2004) Differential eicosapentaenoic acid elevations and altered cardiovascular disease risk factor responses after supplementation with docosahexaenoic acid in postmenopausal women receiving and not receiving hormone replacement therapy. Am J Clin Nutr 79, 765-773.

14. Möhn S, Fuller MF, Ball RO, et al. (2003) Feeding frequency and type of isotope tracer do not affect direct estimates of Lys oxidation in growing pig. J Nutr 133, 3504-3508.

15. Guiguer KR, Drimmie R \& Power M (2003) Validating methods for measuring delta ${ }^{18} \mathrm{O}$ and $\operatorname{delta}^{13} \mathrm{C}$ in otoliths from freshwater fish. Rapid Commun Mass Spectrom 17, 463-471. 
16. Nyachoti CM, de Lange CFM \& Schulze H (1997) Estimating endogenous amino acid flows at the terminal ileum and true ileal amino acid digestibilities in feedstuffs for growing pigs using the homoarginine method. I Anim Sci 75, 3206-3213.

17. Wood PDP (1967) Algebraic model of the lactation curve in cattle. Nature 216, 164-165.

18. Ali TE \& Schaeffer LR (1987) Accounting for covariances among test day milk yields in dairy cows. Can J Anim Sci 67, 637-644.

19. Wilmink JBM (1987) Adjustment of test-day milk, fat and protein yield for age, season and stage of lactation. Livest Prod Sci 16, 335-348.

20. Dijkstra J, France J, Dhanoa MS, et al. (1997) A model to describe growth patterns of the mammary gland during pregnancy and lactation. J Dairy Sci 80, 2340-2354

21. Lopez S, France J, Gerrits WJ, et al. (2000) A generalized Michaelis-Menten equation for the analysis of growth. J Anim Sci 78, 1816-1828.

22. Kebreab E, Schulin-Zeuthen M, Lopez S, et al. (2007) Comparative evaluation of mathematical functions to describe growth and efficiency of phosphorus utilization in growing pigs. J Anim Sci 85, 2498-2507.

23. Thornley JHM \& France J (2007) Mathematical Models in Agriculture, 2nd ed. Wallingford: CABI International pp. 923.

24. Vedenov D \& Pesti GM (2008) A comparison of methods of fitting several models to nutritional response data. J Anim Sci 86, 500-507.

25. Möhn S, Gillis AM, Moughan PJ, et al. (2000) Influence of dietary Lys and energy intakes on body protein deposition and Lys utilization in the growing pig. J Anim Sci $\mathbf{7 8}$ $1510-1519$

26. Kloareg M, Noblet J \& van Milgen J (2007) Deposition of dietary fatty acids, de novo synthesis and anatomical partitioning of fatty acids in finishing pigs. Br J Nutr 97, 35-44.

27. Burdge GC, Jones AE \& Wootton SA (2002) Eicosapentaenoic and docosapentaenoic acids are the principal products of alpha-linolenic acid metabolism in young men. Br J Nutr $\mathbf{8 8}, 355-363$

28. McCloy U, Ryan MA, Pencharz PB, et al. (2004) A comparison of the metabolism of eighteen-carbon ${ }^{13} \mathrm{C}$-unsaturated fatty acids in healthy women. J Lipid Res 45, 474-485.

29. Mayes C, Burdge GC, Bingham A, et al. (2006) Variation in $\left[\mathrm{U}^{13}{ }^{13} \mathrm{C}\right] \alpha$-linolenic acid absorption, beta-oxidation and conversion to docosahexaenoic acid in the pre-term infant fed a DHA-enriched formula. Pediatr Res 59, 271-275.

30. Plourde M, Chouinard-Watkins R, Vandal M, et al. (2001) Plasma incorporation, apparent retroconversion and $\beta$-oxidation of ${ }^{13} \mathrm{C}$-docosahexaenoic acid in the elderly. Nutr Metab 8, 5 .

31. Jones AE, Stolinski M, Smith RD, et al. (1999) Effect of fatty acid chain length and saturation on the gastrointestinal handling and metabolic disposal of dietary fatty acids in women. BrJ Nutr 81, 37-43.

32. Riley PA, Enser M, Nute GR, et al. (2000) Effects of dietary linseed on nutritional value and other quality aspects of pigs muscle and adipose tissue. Anim Prod 71, 483-500.

33. Corino C, Musella M \& Mourot J (2008) Influence of extruded linseed on growth, carcass composition, and meat quality of slaughtered pigs at one hundred ten and one hundred sixty kilograms of live weight. J Anim Sci 86, 1850-1860.

34. Salem N Jr, Wegher B, Mena P, et al. (1996) Arachidonic and docosahexaenoic acids are biosynthesized from their 18-carbon precursors in human infants. Proc Natl Acad Sci US A 93, 49-54.
35. Igarashi M, Ma K, Chang L, et al. (2006) Low liver conversion rate of $\alpha$-linolenic to docosahexaenoic acid in awake rats on a high docosahexaenoate-containing diet. J Lipid Res 47, $1812-1822$

36. Burdge GC \& Wootton SA (2002) Conversion of $\alpha$-linolenic acid to eicosapentaenoic, docosapentaenoic, docosahexaenoic acids in young women. BrJ Nutr 88, 411-420.

37. Abedin L, Lien EL, Vingrys AJ, et al. (1999) The effects of dietary $\alpha$-linolenic acid compared with docosahexaenoic acid on brain, retina, liver, and heart in the guinea pig. Lipids 34, 475-482.

38. Cho HP, Nakamura MT \& Clarke SD (1999) Cloning, expression, and nutritional regulation of the mammalian 46-desaturase. J Biol Chem 274, 471-477.

39. Smink W, van Baal J, Hovenier R, et al. (2009) The role of linoleic and $\alpha$-linolenic acid for synthesis of long chain polyunsaturated fatty acids in liver and brain: a model study with growing pigs. J Anim Sci 87, E-Suppl, 579 Abstr.

40. Sprecher H, Luthria DL, Mohammed BS, et al. (1995) Reevaluation of the pathways for the biosynthesis of polyunsaturated fatty acids. J Lip Res 36, 2471-2477.

41. Stubhaug I, Tocher DR, Bell JG, et al. (2005) Fatty acid metabolism in Atlantic salmon (Salmo salar L.) hepatocytes and influence of dietary vegetable oil. Biochim Biophys Acta 1734, 277-288

42. Park WJ, Kothapalli KS, Lawrence P, et al. (2009) An alternate pathway to long-chain polyunsaturates: the FADS2 gene product $\Delta-8$ desaturates $20: 2 n-6$ and $20: 3 n-3$. J Lipid Res 50, $1195-1202$.

43. Lin YH \& Salem N Jr (2007) Whole body distribution of deuterated linolenic and $\alpha$-linolenic acid and their metabolites in the rat. J Lipid Res 48, 2709-2724.

44. James MJ, Ursin VM \& Cleand GL (2003) Metabolism of stearidonic acid in human subjects: comparison with the metabolism of other $n$-3 fatty acids. Am J Clin Nutr 77, 1140-1145

45. Harris WS, Lemke SL, Hansen SN, et al. (2008) Stearidonic acid-enriched soybean oil increased the omega-3 index, an emerging cardiovascular risk marker. Lipids 43, 805-811.

46. Igarashi M, Zhan ZP, Luo J, et al. (2008) Rat heart cannot synthesize docosahexaenoic acid from circulating alphalinolenic acid because it lacks elongase-2. J Lipid Res 49 , $1475-1735$.

47. Matsuzaka T, Shimano H, Yahagi N, et al. (2002) Dual regulation of mouse $\Delta 5$ - and $\Delta 6$-desaturase gene expression by SREBP-1 and PPAR $\alpha$. J Lipid Res 43, 107-114.

48. Holman RT (1998) The slow discovery of the importance of omega 3 essential fatty acids in human health. J Nutr $\mathbf{1 2 8}$, $427 \mathrm{~S}-433 \mathrm{~S}$

49. Silvestre AM, Petim-Batista F \& Colaco J (2006) The accuracy of seven mathematical functions in modeling dairy cattle lactation curves based on test-day records from varying sample schemes. J Dairy Sci 89, 1813-1821.

50. De Lany JP, Windhauser MM, Champagne CM, et al. (2000) Differential oxidation of individual dietary fatty acids in humans. Am J Clin Nutr 72, 905-911.

51. Molnár D \& Schitz Y (1998) Fat oxidation in nonobese and obese adolescents: effect of body composition and pubertal development. J Pedriat 132, 98-104.

52. Sinclair AJ, Attar-Bashi NM \& Li D (2002) What is the role of $\alpha$-linolenic acid for mammals? Lipids 37, 1113-1123.

53. Burdge GC (2006) Metabolism of $\alpha$-linolenic acid in humans Prostaglandins Leukot Essent Fatty Acids 75, 161-168.

54. Westerterp KR, Smeets A, Lejeune MP, et al. (2008) Dietary fat oxidation as a function of body fat. Am J Clin Nutr $\mathbf{8 7}$, $132-135$. 